\title{
PTMA Gene
}

National Cancer Institute

\section{Source}

National Cancer Institute. PTMA Gene. NCI Thesaurus. Code C39660.

This gene is involved in the mediation of immune function. 